\title{
Modified value-added intellectual coefficient (MVAIC) and traditional financial performance of Indonesian biggest companies
}

\section{Ihyaul Ulum*, Noviar Kharismawati and Dhaniel Syam}

Accounting Department,

University of Muhammadiyah Malang,

Malang, Indonesia

Email: ihyaul.ulum5@gmail.com

Email: noviar@gmail.com

Email:Dhaniel@yahoo.com

*Correspondent author

\begin{abstract}
The purpose of this study is to examine the influences of intellectual capital performance - measured with modified value added intellectual coefficient (MVAIC) - to four traditional financial performances: return on assets, return on equity, market to book value and price earnings ratio. The data were drawn from 50 biggest market capitalisation companies listed in the Indonesia stock exchange for 8 years (2007-2014). It is an empirical study using WarpPLS 3.0 for the data analysis. The finding shows that: MVAIC influences positively to current and future financial performance. It means that MVAIC can be used to predict the future of financial performance. The results extend the understanding of the role of intellectual capital in creating corporate value and building sustainable advantages for companies in emerging economies.
\end{abstract}

Keywords: Indonesian biggest companies; intellectual capital performance; modified value added intellectual coefficient; MVAIC; traditional financial performance.

Reference to this paper should be made as follows: Ulum, I., Kharismawati, N. and Syam, D. (2017) 'Modified value-added intellectual coefficient (MVAIC) and traditional financial performance of Indonesian biggest companies', Int. J. Learning and Intellectual Capital, Vol. 14, No. 3, pp.207-219.

Biographical notes: Ihyaul Ulum is a Lecturer in Accounting Department, Faculty of Economics and Business, University of Muhammadiyah Malang. He just finished my $\mathrm{PhD}$ program in February 2015. He focused on intellectual capital and public sector accounting field of study. Recently, he published his 8th book entitle "Intellectual Capital: measurement model, framework, disclosure and organisational performance".

Noviar Kharismawati was recently graduated from Accounting Department University of Muhammadiyah Malang, Indonesia. Now, She take her master degree in Brawijaya University.

Dhaniel Syam is a senior lecturer in Accounting Department, Faculty of Economics and Business, University of Muhammadiyah Malang. Previosly, he was a Head of Accounting Department. 


\section{Introduction}

The limitation provisions of accounting standards on intellectual capital (IC) had prompted some experts to create models of the measurement and reporting of IC. One of those which most popular in many countries was the value added intellectual coefficient (VAICTM) developed by Pulic (1998). VAIC ${ }^{\text {TM }}$ does not measure the IC, but it measures the impact of IC management (Ulum et al., 2008). The assumption is that if a company has a good and well-maintained IC, then certainly there will be some effects. Those are then measured by Pulic with VAIC ${ }^{\text {TM }}$, thus VAIC ${ }^{\text {TM }}$ is more accurately described as a measure of the performance of IC (intellectual capital performance/ICP) which by Mavridis (2004), Kamath (2007) and Ulum (2009b) was called as business performance indicator.

Based on previous studies about intellectual capital measurement models, Ulum (2015) offered a revised version of Pulic's VAIC ${ }^{\mathrm{TM}}$, namely modified value added intellectual coefficient (MVAIC). This model added the third component of IC, relational capital (RC), measured with marketing costs (Nazari and Herremans, 2007). The latest study by Maji and Goswami (2017) showed that the MVAIC model to some extent captures the structural capital efficiency (SCE) of a firm more efficiently than the original model (VAIC).

VAIC $^{\text {TM }}$ as a measure of ICP has been tested in various contexts of industries and countries. Recent studies used VAIC as a tool to measure the performance of banking companies (Soriya and Narwal, 2015; El-Bannany, 2015). A number of empirical studies have examined the relationship between ICP and direct market performance (Shiri et al., 2012; Zou and Huan, 2011; Wang, 2008). Preceded by Pulic (2000) who took the sample of companies of the FTSE 250, he proved that the ICP (as measured by VAICTM) significantly influences the company's market value. This result was later confirmed by Chen et al. (2005), which used a sample of public companies in Taiwan. The result showed that ICP gives positive effect on the market value and the financial performance of the company, both now and in the future. Similar findings were also indicated in Mosavi et al. (2012), Yalama and Coskun (2007), Ousama and Fatima (2015) and Vishnu and Gupta (2015).

Ulum et al. (2008) that retrieved data from 130 companies of the banking sector in Indonesia in 2004-2006, proved that

1 intellectual capital (VAICTM) influenced the company's financial performance

2 intellectual capital (VAIC ${ }^{\mathrm{TM}}$ ) influenced the financial performance of future companies

3 the average growth of IC (ROGIC) affected the financial performance of future companies.

Furthermore, Ulum et al. (2014) analysed MVAIC to measure the performance of a value-based Indonesian banking sector for 2009-2012. The results proved that MVAIC is a comprehensive model for measuring ICP based on VAIC ${ }^{\text {TM }}$.

This paper tested the effect of MVAIC to companies' performance. We used four traditional financial performances, namely return on assets (ROA), return on equity (ROE), market to book value (M/B) and price earnings ratio (PER). The research data were taken from public companies in Indonesia which were included in category of 50 biggest market capitalisation during the years 2007-2014. 


\title{
1.1 Resource-based theory
}

Resource-based theory (RBT) is one widely accepted theory in the field of strategic management (Newbert, 2007). RBT was delivered for the first time by Wernerfelt (1984) in his pioneer article entitled "A resource-based view of the firm" that combined the idea of 'distinctive competencies' of Selznick (1957) and Penrose (2009) on "definition of the firm as a system of productive resources" (Nothnagel, 2008). But the most influential theory is regarded to an article by Barney (1999) entitled "Firm Resources and Sustained Competitive Excellence", published in the Journal of Management.

Edith Penrose was one of the first to recognise the importance of the resource to the company's competitiveness. In 1959, she stated:

\begin{abstract}
“...A firm's growth, both internally and then externally through merger, acquisition and diversification, is due to the manner in which its resources are employed..... a firm consists of 'a collection of productive resources'... these resources may only contribute to a firm's competitive position to the extent that they are exploited in such a manner that their potentially valuable services are made available to the firm" (Penrose, 2009).
\end{abstract}

Developing the breakthrough concept stated by Penrose, Wernerfelt, in the first attempt to formalise the RBT (he uses the term resource-based view), stated that "to the company, resources and products are the two sides of coins" (Wernerfelt, 1984). In other words, when the company's performance is directly driven by the product, it also indirectly (but surely) is driven by the resources that take part in the production process (Newbert, 2007).

Resource-based theory states that the company has the resources to make it possessing competitive excellence and is able to direct the company to have a good longterm performance. Valuable and rare resources can be directed to create a competitive excellence so that the owned resources become durable and not easily imitated, transferred or replaced. Barney and Arikan (2001) stated that "resources are the tangible and intangible assets firms use to conceive of and implement Reviews their strategies".

There are two assumptions inherent in RBT (Nothnagel, 2008); they are resource heterogeneity and resource immobility. Resource heterogeneity (also called resource diversity) alludes whether a company has the resources or capabilities that are also owned by other competitors, so that resources are not considered to have competitive excellence. While the resource immobility refers to a resource that is difficult for competitors, because it is difficult to obtain or it is very expensive if uses the resource.

Barney (1991) stated that in the perspective of RBT, firm resources include all assets, capabilities, organisational processes, the company's attributes, information, knowledge and others that are controlled by companies that allow companies to understand and implement strategies to improve efficiency and effectiveness of the company.

Resource-based theory is very appropriate to describe the study of IC, especially in the context of the relationship between ICP and market performance. In the perspective of IC, intangible assets of companies are classified in three main categories: human capital, structural capital and customer capital (Bontis, 1998).

According to Pulic and Kolakovic (2003), each company has unique knowledge, skills, values and solutions - intangible resources - which can be transformed into a 'value' in the market. Intangible resource management can help companies to achieve competitive excellence, increase productivity and market value. The explanation from Pulic and Kolakovic (2003) is in line with the logic of Barney (1991) when describing 
the relationship between the two assumption resources in RBT with four attributes of a potential resource for competitive excellence.

\subsection{Intellectual capital and MVAIC}

Research on IC has been started since 1990 (Choong, 2008). Human capital was a main focus of research on IC at that time, and the researchers tested the role of 'knowledge' in the IC (Santoso, 2011). In fact, the study of intangible assets has been conducted since the 1940s, started by Davis et al. (1940) who examined the role of intangible assets, such as goodwill, which was the value for the organisation. Later, Itami and Roehl (1987) introduced the concept of intangible assets as invisible assets. Invisible assets include information-based resources such as technological knowledge, customer knowledge and market knowledge (Hall, 1992).

Intellectual capital is one of accounting study fields. This is, for instance, very clearly confirmed by Guthrie et al. (1999) who used the term intellectual capital accounting (ICA) when reviewing the 2,662 articles of 10 international journals in the field of Accounting. They found that 423 of those articles examined the ICA. The same assertion was stated by Dumay (2014) when calculating the number of citations in articles on IC in the Journal of Intellectual Capital compared with the number of citations in articles published in 19 other international journals.

Intellectual capital is a company resource that is important to win and maintain the competitive excellence (Pulic and Kolakovic, 2003), the performance advantage of the intellectual capital of the company is believed to be an effect on the financial performance. The higher the ICP, the better the financial performance.

Different terms are used to refer to the same object, namely intangible assets. For example, invisible assets (Itami, 1991), intellectual capital (Brooking, 1997; Stewart, 1997), immaterial values (Sveiby, 1997) and intangibles (Gu and Lev, 2001). Choong (2008) presented the definitions of some terms that refer to the IC as shown in Table 1.

Table 1 Term of intellectual capital

\begin{tabular}{lll}
\hline Scholar & Term & Definition \\
\hline Itami (1991) & Invisible assets & $\begin{array}{l}\text { Intangible assets are invisible assets that include a wide } \\
\text { range of activities such as technology, consumer trust, } \\
\text { brand image, corporate culture, and management skills }\end{array}$ \\
Hall (1992) & Intangible asset & $\begin{array}{l}\text { Intangible assets are value drivers that transform } \\
\text { productive resources into value-added assets }\end{array}$ \\
Smith (1994) & $\begin{array}{l}\text { Intellectual } \\
\text { property }\end{array}$ & $\begin{array}{l}\text { Intangible assets are all the elements of a business } \\
\text { enterprise that exist in addition to working capital and } \\
\text { tangible assets. They are the elements, after working } \\
\text { capital and tangible assets that make the business work } \\
\text { and are often the primary contributors to the earning } \\
\text { power of the enterprise. Their existence is dependent on } \\
\text { the presence, or expectation, of earnings }\end{array}$ \\
\hline
\end{tabular}


Table 1 Term of intellectual capital (continued)

\begin{tabular}{lll}
\hline Scholar & Term & Definition \\
\hline $\begin{array}{l}\text { Brooking } \\
\text { (1997) }\end{array}$ & $\begin{array}{l}\text { Intellectual } \\
\text { capital }\end{array}$ & $\begin{array}{l}\text { IC as "market assets, human-centred assets, intellectual } \\
\text { property assets and infrastructure assets" }\end{array}$ \\
$\begin{array}{l}\text { Edvinsson and } \\
\text { Malone (1997) }\end{array}$ & $\begin{array}{l}\text { Intellectual } \\
\text { capital dan } \\
\text { intangible assets }\end{array}$ & $\begin{array}{l}\text { Intangible assets are those that have no physical } \\
\text { existence but are still of value to the company }\end{array}$ \\
Sveiby (2006) & $\begin{array}{l}\text { Immaterial values } \\
\text { IC has three dimensions (employee competence, } \\
\text { internal structure and external structure) }\end{array}$ \\
\hline
\end{tabular}

Source: Ulum (2015)

\subsection{Modified VAIC}

Modified VAIC is a comprehensive measure of IC based on VAIC ${ }^{\text {TM }}$ model. It is started with calculating VA by using the formula proposed by Pulic (2000):

$$
\mathrm{VA}=\mathrm{OP}+\mathrm{EC}+\mathrm{D}+\mathrm{A}
$$

where $\mathrm{OP}$ is operating profit, EC is employee costs, $\mathrm{D}$ is depreciation and $\mathrm{A}$ is amortisation. According to Pulic (2004), VAIC TM is the sum of intellectual capital efficiency (ICE) and capital employed efficiency (CEE), while ICE is human capital efficiency (HCE) plus SCE. The formula to calculate HCE is as follows (Pulic, 2000):

$$
\mathrm{HCE}=\mathrm{VA} / \mathrm{HC}
$$

where HCE, human capital efficiency: ratio of VA to HC; VA, value added; HC, human capital: total salaries and wages.

$$
\mathrm{SCE}=\mathrm{SC} / \mathrm{VA}
$$

where SCE, structural capital efficiency: ratio of SC to VA; SC, structural capital: VA-HC.

While in this MVAIC, Ulum (2015) adds the third component of IC, i.e. relational capital efficiency (RCE). RCE illustrates the efficiency of investment in relational aspect. In this context, relational capital is proxied by marketing costs:

$$
\mathrm{RCE}=\mathrm{RC} / \mathrm{VA}
$$

where RCE, relational capital efficiency: ratio of $\mathrm{RC}$ to $\mathrm{VA}$; $\mathrm{RC}$, relational capital: marketing costs (Nazari and Herremans, 2007).

Pulic (2004) argued that to have a broad overview of the efficiency of all resources, it is important to take the financial capital and physical capital (capital employed) as one of the considerations. The efficiency of capital employed is calculated by (Pulic, 2000):

$$
\mathrm{CEE}=\mathrm{VA} / \mathrm{CE}
$$

where CEE, capital employed efficiency: ratio of VA to CE; CE, capital employed: book value of total assets.

Thus, the complete formula of MVAIC is:

$$
\begin{aligned}
& \text { MVAIC }=\mathrm{ICE}+\mathrm{CEE} \\
& \mathrm{ICE}=\mathrm{HCE}+\mathrm{SCE}+\mathrm{RCE} \\
& \mathrm{MVAIC}=\mathrm{HCE}+\mathrm{SCE}+\mathrm{RCE}+\mathrm{CEE}
\end{aligned}
$$


Figure 1 Formulation of MVAIC

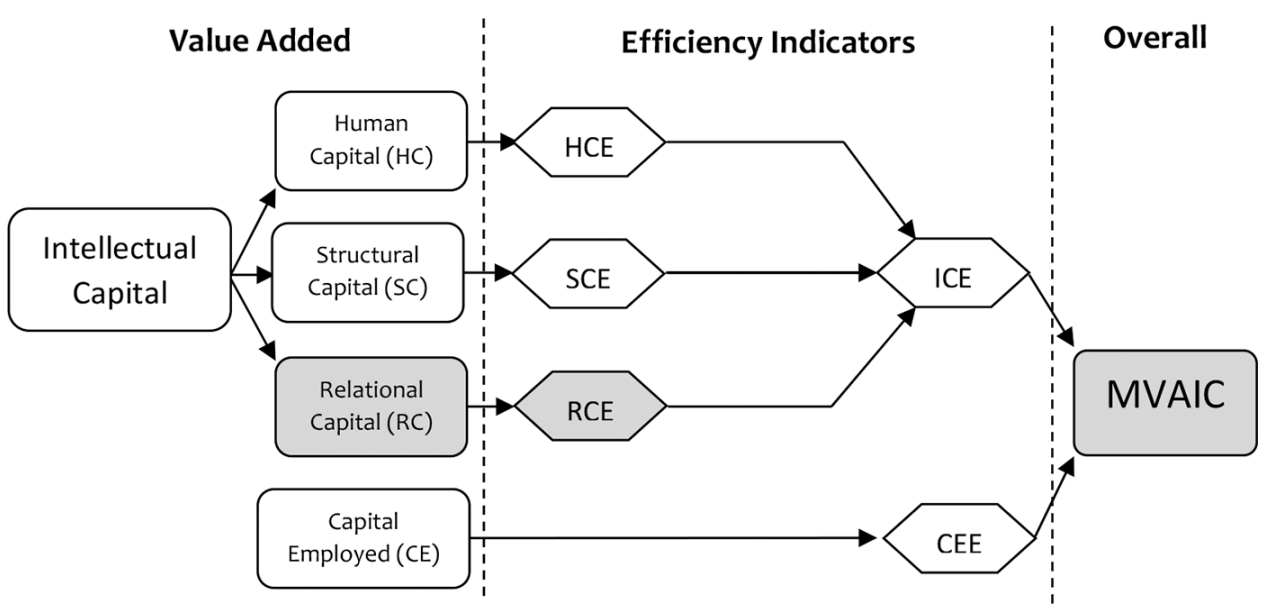

Source: Modified from Laing et al. (2010)

\subsection{Hypothesis development}

Referring to the assumption that the IC is a company resource that is important to win and maintain a competitive excellence (Pulic and Kolakovic, 2003), the IC performance advantages of the company are believed to be an effect on the financial performance. The higher the IC performance, the better the financial performance. Companies with a good performance of IC are believed to be able to manage all its resources efficiently.

A number of empirical studies have shown that the performance of IC (ICP) affects the traditional financial performance, Chen et al. (2005), for example, investigated the relationship between (performance) IC with financial performance as measured by ROE, $\mathrm{M} / \mathrm{B}$, ROA, growth in revenues (GR) and employee productivity (EP). They used a public company in Taiwan as the research object and used VAIC as a measure of IC performance. The results showed that the ICP (VAIC) significantly gave positive effect on financial performance.

In 2007, Tan et al. (2007) investigated the influence of IC (performance) - measured by VAIC - on company performance. Using the 150 public companies in Singapore as samples, the study stated that VAIC significantly influenced the company's performance, as measured by profitability, EPS (earning per share) and ASR (annual stock returns). Consistent with the results of Chen et al. (2005), this study also proved that besides affecting the financial performance in the present, VAIC is also affecting the financial performance in the future. That is, VAIC can be used for predicting company's financial performance.

Referring to the two previous studies, (Ulum, 2009a) examined the effect of IC (VAIC) to the financial performance of banks in Indonesia (measured by ROA, EPS and ASR). The results proved that the VAIC has significant effect on ROA. In addition, this study also confirmed that the VAIC can be used to predict a company's financial performance in the future.

Later, Kamal et al. (2011), Zehri et al. (2012) and Khanqah et al. (2012) also reported results that are consistent with the previous studies. Using different setting countries - 
Malaysia, Iran and Tunisia - all the three of those studies demonstrated that the performance of IC (VAIC) significantly affected the traditional financial performance. In the context of Indonesia, Basuki and Kusumawardhani (2012) also confirmed the results which were consistent with previous studies.

Ulum et al. (2014) have tested MVAIC as a measure of the performance of the intellectual capital of the banking company in Indonesia. The results showed that MVAIC gave positive effect on market capitalisation. MVAIC was also shown to affect the profitability of ROA.

The studies are in line with the logic of the theory of RBT which states that firms with superior, scarce and difficult to imitate by competitor resources will be able to win the competition, and the IC is a resource in question (Marzo, 2014). Based on the arguments and explanation of research results, this study formulated hypotheses as follows:

H1: There is a positive effect of ICP (MVAIC) on the financial performance of traditional.

Intellectual capital does not only give positive effect on the company's performance in the ongoing year, but it also predicts future financial performance. Chen et al. (2005), using a sample of public companies in Taiwan, proved that IC positively affected the market value and the financial performance of the company. In fact, Chen et al. (2005) also proved that the IC can be one of indicators to predict the future performance of the company.

In line with Chen et al. (2005), Tan et al. (2007) and Ulum (2009a) showed a significant result of the influence of IC against future corporate performance. IC can be the most appropriate indicator to predict the company's financial performance in the future (Bontis and Fitz-enz, 2002). To re-examine the proposition, the second hypothesis of this study is:

H2: There is a positive effect of ICP (MVAIC) on the financial performance in the future.

Figure 2 Empirical research model

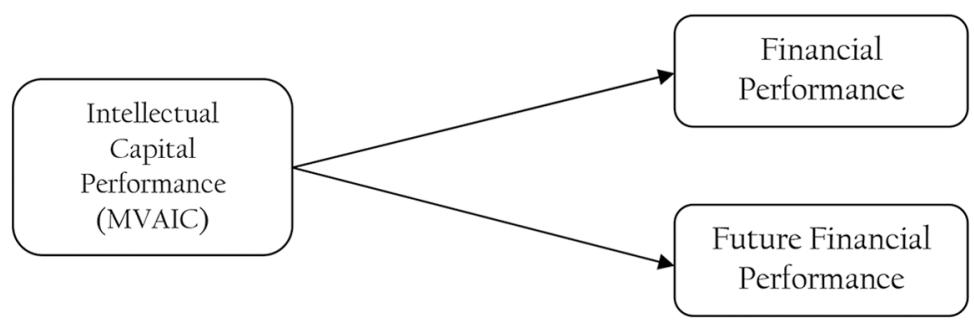

\section{Method}

The populations of this study were public companies (listed on Indonesia Stock Exchange) which were mentioned in 50 biggest market capitalisation in 2007-2014. Sampling step was done by purposive sampling, with the following criteria 
1 The public companies which were included in the top 10 of 50 Biggest Market

Capitalisation categories during the years 2007 to 2014.

2 The companies which published financial statements presented in rupiah during the years 2007 to 2014 .

The independent variable in this study was the ICP. The measurement of ICP used MVAIC. The stages of MVAIC calculation were:

The dependent variable in this research was financial performance. The measurement of company performance used ROA, ROE, M/B and PER. ROA reflects the business benefits and efficiency in the use of total assets (Brigham and Wachowicz, 2008):

$\mathrm{ROA}=$ net profit $/$ total assets.

ROE measures a company's ability to generate profits based on a specific share capital. This ratio was a measurement of profitability from the perspective of shareholders:

$$
\mathrm{ROE}=\text { net profit/equity. }
$$

Market to book value ratios is the ratio of the market price of a share to the book value indicating investors' views on the company (Brigham and Wachowicz, 2008). $\mathrm{M} / \mathrm{B}=$ market price per share/book value per share. $\mathrm{PER}$ is an analysis tool used to look at the stock price to its earnings. The companies which are expected to have high growth have high PER.

PER $=$ market price per share/earnings per share.

We use partial least square (PLS) to analyse the data. PLS is a method of settling the structural equation modelling (SEM), which is in this case (according to the research purpose), is more precise than the other SEM techniques (Ghozali, 2006). We predict that the effect of ICP to company's financial performance may take place in the coming year(s). Therefore, we conduct tests using lag-1 and lag-2. In addition, the use of lag-1 and lag-2 is to prove that MVAIC can be used to predict future financial performances.

\section{Results and discussion}

\subsection{Outer test model hypothesis}

The first hypothesis proposed in this study was the effect of ICP on financial performance in 2007-2014. In this context, intellectual capital was tested on the financial performance in the same year.

Table 2 represents WarpPLS results. From "model fit indices and $P$ value", we know that the value of APC (average path coeffecient) $=0.686, P<0.001$, ARS (average $\mathrm{R}-$ squared $)=0.470, P=0.001$, AVIF (average variances inflation factor) $=1,000$, Good if $<5$. The conditions of WarpPLS stated that the $p$-value for the APC and ARS should be less than 0.05 (significant). In addition, as a multicollinearity indicator, AVIF must be smaller than 5. Referring to these provisions, it could be concluded that this research model was fit. Similar results were shown when we are running test for second hypothesis, both with lag-1 and lag-2. 
Table 2 Model fit indices

\begin{tabular}{lcc}
\hline Hypothesis 1 & Hypothesis 2 (lag-1) & Hypothesis 2 (lag-1) \\
\hline Model fit indices and $P$ values & & \\
APC $=0.686, P<0.001$ & APC $=0.702, P<0.001$ & APC $=0.641, P<0.001$ \\
ARS $=0.470, P=0.001$ & ARS $=0.493, P=0.002$ & ARS $=0.410, P=0.013$ \\
AVIF $=1.000$, good if $<5$ & AVIF $=1.000$, good if $<5$ & AVIF $=1.000$, good if $<5$ \\
\hline
\end{tabular}

Table 3 presents the value of path coefficient and its P-value for all direct connections. Path coefficient of the first hypothesis (ICP- PERF (Performance)) was 0.686, and it was significant at $P<0.001$. Similar results were shown for the second hypothesis, both with lag-1 and lag-2.

Table 3 Path coefficients and $P$ values

\begin{tabular}{lcc}
\hline Hypothesis 1 & Hypothesis 2 (lag-1) & Hypothesis 2 (lag-2) \\
\hline Path coefficients and P values & & \\
ICP-PERF (0.686) & ICP-PERF (0.702) & ICP-PERF (0.641) \\
$P<0.001$ & $P<0.001$ & $P<0.001$ \\
\hline
\end{tabular}

\subsection{Inner test model hypothesis 1 and 2}

The inner models test of the first and second hypotheses 1 and 2 was done by looking at $R$-squared and $Q$-squared. Table 4 resumes the results of hypothesis test with WarpPLS.

Table 4 Inner model test result for $\mathrm{H} 1$ and $\mathrm{H} 2$

\begin{tabular}{lcccc}
\hline & & $R$-squared & Q-squared & Full collinearity \\
\hline Hypothesis1 & & 0.470 & 0.460 & 1.641 \\
Hypothesis 2 & Lag 1 & 0.493 & 0.499 & 1.630 \\
& Lag 2 & 0.410 & 0.419 & 1.334 \\
\hline
\end{tabular}

The test results in Table 4 showed that in our model there was neither vertical nor lateral multicollinearity. It could be seen from the full collinearity VIF (variances inflation factor) value that was below 3.3 for all variables. Based on statistical analysis shown, the performance of intellectual capital (MVAIC) affects positively the company's financial performance. It can be concluded that the first hypothesis was accepted.

The second hypothesis proposed in this study was that the performance of intellectual capital influences the future financial performance. In this context, the performance of ICs to the financial performance was tested with lag 1 and lag 2 years. The results of testing the second hypothesis showed that the path coefficient and $P$ value lag- 1 showed 0.702 and $P<0.001$ and the path coefficients and $P$ value of $\operatorname{lag} 2$ was 0.641 and $P<0.001$. $R$-squared value of lag 1 year was 0.493 which meant that the ICP was able to explain the variable of future financial performance of $49.3 \%$.

$R$-squared for 2-year lag was 0.410 which meant that the ICP was able to explain the variable of future financial performance by $40 \%$. And $Q$-squared values in Table 4 showed that the lag 1 year amounted to 0.499 and lag of 2 years was 0.419 which meant that our model showed good predictive validity for worth above zero. Thus it can be 
concluded that the second hypothesis is accepted. The results of this study confirmed the study conducted by Chen et al. (2005), Tan et al. (2007) and Ulum (2009a) that the performance of intellectual capital affects the financial performance and the performance of intellectual capital affects the financial performance in the future.

Referring to the assumption that the IC is a resource company that is important to win and maintain a competitive excellence (Pulic and Kolakovic 2003), the excellence of IC performance of a company is believed to affect the financial performance. The higher IC performance, the better the financial performance. Companies that have good performance of IC is believed to be able to manage all its resources efficiently.

Based on RBT, both ICP and profitability are resources that are owned by the company to win the competition. The excellence inherent in both of these can be the advantage for the company. It is important for companies to ensure that all available resources are oriented in an effort to maximise profits for the interests of shareholders and to sustain the organisation through good management of intangible assets (including IC) in the interests of stakeholders.

The results of this study are consistent and support a number of empirical studies that have shown the performance of IC (ICP) effects on financial performance. For example: Chen et al. (2005) in Taiwan, Tan et al. (2007) in Singapore, Ulum (2009a) and Basuki and Kusumawardhani (2012) for the Indonesian context, and later, Kamal et al. (2011), Zehri et al. (2012) and Khanqah et al. (2012) also reported results which are consistent with the previous studies. In the Indonesian context, also, it was confirmed that the results are consistent with previous studies. The studies are in line with the logic of RBT theory which states that firms with superior, scarce and difficult to imitate by competitors resources will be able to win the competition, and the IC is a resource in question (Marzo, 2014).

This proved that intellectual capital affected the performance of the traditional financial performance. When viewed from the perspective of RBT, superior intellectual capital owned by a company was the organisation's resources as capital for managing organisations better. The excellence of the intellectual capital of the company is believed to affect the financial performance.

\section{Conclusion}

Based on the test results and discussions as presented in the previous section, it can be concluded that based on the results of testing with 3.0 WarpPLS, it is statistically proven that there is a significant effect on ICP (MVAIC) to the company's financial performance during the 8 years of observations from 2007 to 2014. Thus, it means that $\mathrm{H} 1$ is accepted. And output of WarpPLS results proved statistically that there is significant effect on ICP (MVAIC) to the company's future financial performance. Thereby, the $\mathrm{H} 2$ is accepted.

Theoretically, this study supports the RBT perspectives. Barney (1991) stated that firm resources included all assets, capabilities, organisational processes, information and knowledge controlled by a firm that enable the firm to conceive of and implement strategies that improve its efficiency and effectiveness.

This study used MVAIC in measuring the performance of intellectual capital, while MVAIC is not yet fully considered as a measure of intellectual capital intact. Supposedly, SCE in MVAIC is not just built on the ratio of VA-HC. Consequently, it becomes irrational, because it means that the efficiency of the SC will be high only if the 
efficiency of $\mathrm{HC}$ is low. It is expected that the future researches may complete MVAIC models by adding new sizes for structural components of capital. The extended VAIC model (Nazari and Herremans, 2007) and/or E-VAIC+ (Ulum, 2014) might be used to.

\section{References}

Barney, J.B. (1991) 'Firm resources and sustained competitive advantage', Journal of Management, Vol. 17, No. 1, pp.99-120.

Barney, J.B. (1999) 'How a firms capabilities effect boundary decisions', Sloan Management Review, Vol. 40, No. 3, pp.137-145.

Barney, J.B. and Arikan, A.M. (2001) 'The resource-based view: origins and implications', in Hitt, M.A., Freeman, R.E. and Harrison, J.S. (Eds.): The Blackwell Handbook of Strategic Management, Blackwell Publishing, Oxford, pp.124-188.

Basuki and Kusumawardhani, T. (2012) 'Intellectual capital, financial profitability, and productivity: an exploratory study of the Indonesian pharmaceutical industry', Asian Journal of Business and Accounting, Vol. 5, No. 2, pp.41-68.

Bontis, N. (1998) 'Intellectual capital: an exploratory study that develops measures and models', Management Decision, Vol. 36, No. 2, pp.63-76.

Bontis, N. and Fitz-enz, J. (2002) 'Intellectual capital ROI: a causal map of human capital antecedents and consequents', Journal of Intellectual Capital, Vol. 3, No. 3, pp.223-247.

Brigham, E.F. and Wachowicz, J.M. (2008) Fundamentals of Financial Management, 13th ed., Pearson Education Limited, London, UK.

Brooking, A. (1997) Intellectual Capital: Core Asset for the Third Millennium Enterprise, Thomson Business Press, London.

Chen, M.C., Cheng, S.J. and Hwang, Y. (2005) 'An empirical investigation of the relationship between intellectual capital and firms' market value and financial performance', Journal of Intellectual Capital, Vol. 6, No. 2, pp.159-176.

Choong, K. (2008) 'Intellectual capital: definitions, categorization and reporting models', Journal of Intellectual Capital, Vol. 9, No. 4, pp.609-638.

Davis, F.H., Cloake, T.R., Fedde, A.S. and Horne, H.A. (1940) 'Intangible assets', New York Certified Public Accountant, Vol. 1, No. 1, p.33.

Dumay, J.C. (2014) ' 15 years of the journal of intellectual capital and counting: a manifesto for transformational IC research', Journal of Intellectual Capital, Vol. 15, No. 1, pp.2-37.

El-Bannany, M. (2015) 'Explanatory study about the intellectual capital performance of banks in Egypt', International Journal of Learning and Intellectual Capital, Vol. 12, No. 3, pp.270-286.

Edvinsson, L. and Malone, M.S. (1997) Intellectual Capital: Realizing Your Company's True Value by Finding Its Hidden Brainpower, New York, HarperCollins

Ghozali, I. (2006) Structural Equation Medeling; Metode Alternatif Dengan PLS, Badan Penerbit Universitas Diponegoro, Semarang.

Gu, F. and Lev, B. (2013) Markets in Intangibles: Patent Licensing 2001 [cited 6 September 2013]. Available at: http://ssrn.com/abstract=275948

Guthrie, J., Petty, R., Ferrier, F. and Wells, R. (1999) 'There is no accounting for intellectual capital in Australia: review of annual reporting practices and the internal measurement of intangibles within Australian organisations', International Symposium Measuring and Reporting Intellectual Capital: Experiences, Issues and Prospects, OECD, Amsterdam.

Hall, R. (1992) 'The strategic analysis of intangible resources', Strategic Management Journal, Vol. 13, No. 2, p.135.

Itami, H. (1991) Mobilizing Invisible Assets, Harvard University Press, Cambridge, MA. 
Itami, H. and Roehl, T.W. (1987) Mobilizing Invisible Assets, Harvard University Press, Cambridge.

Kamal, M.H.M., Mat, R.C., Rahim, N.A., Husin, N. and Ismail, I. (2011) 'Intellectual capital and firm performance of commercial banks in Malaysia', Asian Economic and Financial Review, Vol. 2, No. 4, pp.577-590.

Kamath, G.B. (2007) 'The intellectual capital performance of Indian banking sector', Journal of Intellectual Capital, Vol. 8, No. 1, pp.96-123.

Khanqah, V.T., Khosroshahi, M.A. and Ghanavati, E. (2012) 'An empirical investigation of the impact of intellectual capital on firms' market value and financial performance: evidence from Iranian companies', International Journal of Management Business Research, Vol. 2, No. 1, pp.1-12.

Laing, G., Dunn, J. and Hughes-Lucas, S. (2010) 'Applying the VAIC'm model to Australian hotels', Journal of Intellectual Capital, Vol. 11, No. 3, pp.269-274.

Maji, S.G. and Goswami, M. (2017) 'Intellectual capital and firm performance in India: a comparative study between original and modified value added intellectual coefficient model', International Journal of Learning and Intellectual Capital, Vol. 14, No. 1, pp.76-89.

Marzo, G. (2014) 'Improving internal consistency in IC research and practice: IC and the theory of the firm', Journal of Intellectual Capital, Vol. 15, No. 1, pp.38-64.

Mavridis, D.G. (2004) 'The intellectual capital performance of the Japanese banking sector', Journal of Intellectual Capital, Vol. 5, No. 3, pp.92-115.

Mosavi, S.A., Nekoueizadeh, S. and Ghaedi, M. (2012) 'A study of relations between intellectual capital components, market value and finance performance', African Journal of Business Management, Vol. 6, No. 4, pp.1396-1403.

Nazari, J.A. and Herremans, I.M. (2007) 'Extended VAIC model measuring intellectual capital components', Journal of Intellectual Capital, Vol. 8, No. 4, pp.595-609.

Newbert, S.L. (2007) 'Empirical research on the resource-based view of the firm: an assessment and suggestions for future research', Strategic Management Journal, Vol. 28, pp.121-147.

Nothnagel, K. (2008) Empirical Research within Resource-Based Theory: A Meta-Analysis of the Central Propositions, Frankfurt, Germany.

Ousama, A.A. and Fatima, A.H. (2015) 'Intellectual capital and financial performance of Islamic banks', International Journal of Learning and Intellectual Capital, Vol. 12, No. 1, pp.115.

Penrose, E. (2009) The Theory of the Growth of the Firm, 4th ed., Oxford University Press, New York.

Pulic, A. (1998) 'Measuring the performance of intellectual potential in knowledge economy', in The 2nd McMaster World Congress on Measuring and Managing Intellectual Capital, Austria.

Pulic, A. (2000) MVA and VAIC TM Analysis of Randomly Selected Companies from FTSE 250, Austrian Intellectual Capital Research Center, Graz, London.

Pulic, A. (2004) 'Intellectual capital - does it create or destroy value?', Measuring Business Excellence, Vol. 8, No. 1, pp.62-68.

Pulic, A. and Kolakovic, M. (2006) Value Creation Efficiency in the New Economy 2003 [cited 3 December 2006]. Available at: www.vaic-on.net.

Santoso, E. (2011) Intellectual Capital in Indonesia: The Influence on Financial Performance of Banking Industry, Doctor of Management, University of Phoenix.

Shiri, M.M., Mousavi, K., Pourreza, A. and Ahmadi, S. (2012) 'The effect of intellectual capital on market value added', Journal of Basic and Applied Scientific Research, Vol. 2, No. 7, pp.7214-7226.

Soriya, S. and Narwal, K.P. (2015) 'Intellectual capital performance in Indian banks: a panel data analysis', International Journal of Learning and Intellectual Capital, Vol. 12, No. 2, pp.103-121.

Stewart, T.A. (1997) Intellectual Capital, Nicholas Brealey Publishing, London. 
Sveiby, K.E. (1997) The 'Invisible' Balance Sheet 1997 [cited 19 November 2006]. Available from http://www.sveiby.com.

Tan, H.P., Plowman, D. and Hancock, P. (2007) 'Intellectual capital and financial returns of companies', Journal of Intellectual Capital, Vol. 8, No. 1, pp.76-95.

Ulum, I. (2009a) 'Intellectual capital dan kinerja keuangan perusahaan; sebuah perspektif sektor perbankan Indonesia', Jurnal Humaniora, Vol. 6, No. 2, PP.54-59.

Ulum, I. (2009b) 'Intellectual capital performance sektor perbankan di Indonesia', Jurnal Akuntansi dan Keuangan (Terakreditasi Dikti), Vol. 10, No. 2, pp.77-84.

Ulum, I. (2014) 'Extended VAIC plus (EVAIC+); a comprehensive measurement model of intellectual capital performance', First International Conference on Future Business Environment and Innovation, FEB University of Muhammadiyah Malang, Malang.

Ulum, I. (2015) Intellectual Capital: Model Pengukuran, Framework Pengungkapan, dan Kinerja Organisasi, UMM Press, Malang.

Ulum, I., Ghozali, I. and Chariri, A. (2008) 'Intellectual capital dan kinerja keuangan perusahaan; sebuah analisis dengan pendekatan partial least squares', Simposium Nasional Akuntansi XI, Ikatan Akuntan Indonesia Kompartemen Akuntan Pendidik, Universitas Tanjung Pura, Pontianak.

Ulum, I., Ghozali, I. and Purwanto, A. (2014) 'Intellectual capital performance of Indonesian banking sector: a modified VAIC (MVAIC) perspective', Asian Journal of Finance \& Accounting, Vol. 6, No. 6, pp.103-123.

Vishnu, S. and Gupta, V.K. (2015) 'Performance of intellectual capital in Indian healthcare sector', International Journal of Learning and Intellectual Capital 2, Vol. 12, No. 1, pp.47-60.

Wang, J.C. (2008) 'Investigating market value and intellectual capital for S\&P 500', Journal of Intellectual Capital, Vol. 9, No. 4, pp.546-563.

Wernerfelt, B. (1984) 'A resource-based view of the firm', Strategic Management Journal, Vol. 5, pp.171-180.

Yalama, A. and Coskun, M. (2007) 'Intellectual capital performance of quoted banks on the Istanbul stock exchange market', Journal of Intellectual Capital, Vol. 8, No. 2, pp.256-271.

Zehri, C., Abdelbaki, A. and Bouabdellah, N. (2012) 'How intellectual capital affects a firm's performance?', Australian Journal of Business and Management Research, Vol. 2, No. 8, pp.24-31.

Zou, X. and Huan, T.C. (2011) 'A study of the intellectual capital's impact on listed bank's performance in China', African Journal of Business Management, Vol. 5, No. 12, pp.5001-5009. 
Article submission and peer-review system

\section{Inderscience Submissions Dashboard}

Support \& Documentation
Inderscience Home

\begin{tabular}{|l|l|l|l|l|}
\hline Submission ID & Submission Title & Submission Date & Action & Status \\
\hline IJLIC-2449 & $\begin{array}{l}\text { Modified Value Added } \\
\text { Intellectual Coefficient } \\
\text { (MVAIC) and traditional } \\
\text { financial... }\end{array}$ & 29-Jul-2016 & View Details & Admitted into Production \\
\hline
\end{tabular}

\section{STATUS GUIDE}

- Incomplete - Article submission has not been completed.

- Screening - Submission is being screened to filter out incomplete or unsuitable content, such as author identifying details.

- Removed - Article has been removed from the submission process by the Submissions Manager.

- Query with Author - Editor has asked the Author to check their submission.

- Under review - Submission has been screened and is undergoing peer-review.

- Author Revising - Editor has asked the Author to amend their article in light of Reviewer recommendations

- Re-Review waiting - Author's amended article is waiting to be sent to Reviewers.

- Re-Reviewing - Reviewers are assessing the Author's amended article.

- Final Review - Editor is considering the reviews and making the final decision whether to publish.

- Rejected - Editor has considered the Author's revised submission and has rejected it.

- Accepted - Editor has accepted the submission for publication.

- Quality Assurance - Author's Final Version has been uploaded and is being processed to determine whether it meets our quality requirements and anti-plagiarism standards.

- QA completed for AFV - Author's Final Version has cleared the quality requirements and anti-plagiarism checks

- Admitted into Production - Author's Final Version is now in the process towards publication.

- Assigned to Typesetter - Journal Manager has assigned the article to a Typesetter.

- Typesetter to Author for First Proof - Article has been typeset and the first proof sent to the Author for checking.

- Author to Typesetter for Amends - Author has returned the article proof for the Typesetter to amend.

- Typesetter to Author for Final Proof - Corrected proof has been sent to the Author for final approval.

- Author to Typesetter - Proof Approved - Author confirms approval by returning to the Typesetter the final changes to the article proof.

- Entering Publication Schedule - Article is now entering the publication schedule.

- Authorised for publishing - Article has been authorised for publishing.

- Complete for Publication - Article is ready to be published

- Article is available online - Article is available online. 
Article submission and peer-review system

\section{Submission Monitoring}

From this page you can:

- view and edit your article's metadata

- add authors

- submit new files

- check the progress of the review process

- view your correspondence with the Editor.

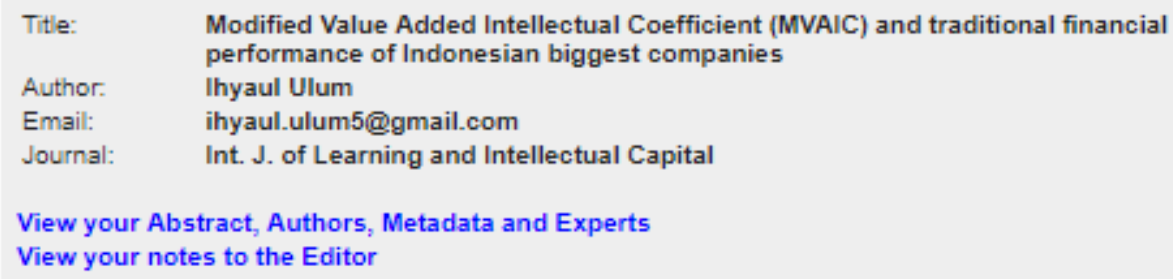

Original Submission:

Uploaded Revised File:

Agreement File:

Author's final version:

Final Published Version:

Supplementary File:

Supplementary File:

Supplementary File:

Add Supplementary Files

\section{6_IJLIC_2449.pdf 2017_IJLIC_2449_ARV.docx 2017_IJLIC_2449_agr.zip 2017_IJLIC_2449_AAV.docx 2017_IJLIC_2449_FPV.pdf}

[04 Aug 2016]

[10 Apr 2017]

[30 Apr 2017]

[30 Apr 2017]

[10 Aug 2017]

2016_IJLIC_2449_sup520.pdf [29 Jul 2016] 2017_IJLIC_2449_sup1690_docx [10 Apr 2017] 2017_IJLIC_2449_sup1691.docx [10 Apr 2017]

$+x$

$+x$

\section{Author article proofs}

Article received from Typesetter for first proof. 2017_IJLIC_2449_TAV.pdf

Proof reply send to Typesetter:

2017_IJLIC_2449_ATV.pdf

1st Amendment Sheet:

2017_IJLIC_2449_ATVAS1.doc

Article received from Typesetter for final proof: 2017_IJLIC_2449_TAFPV.pdf

Proof reply send to Typesetter: 


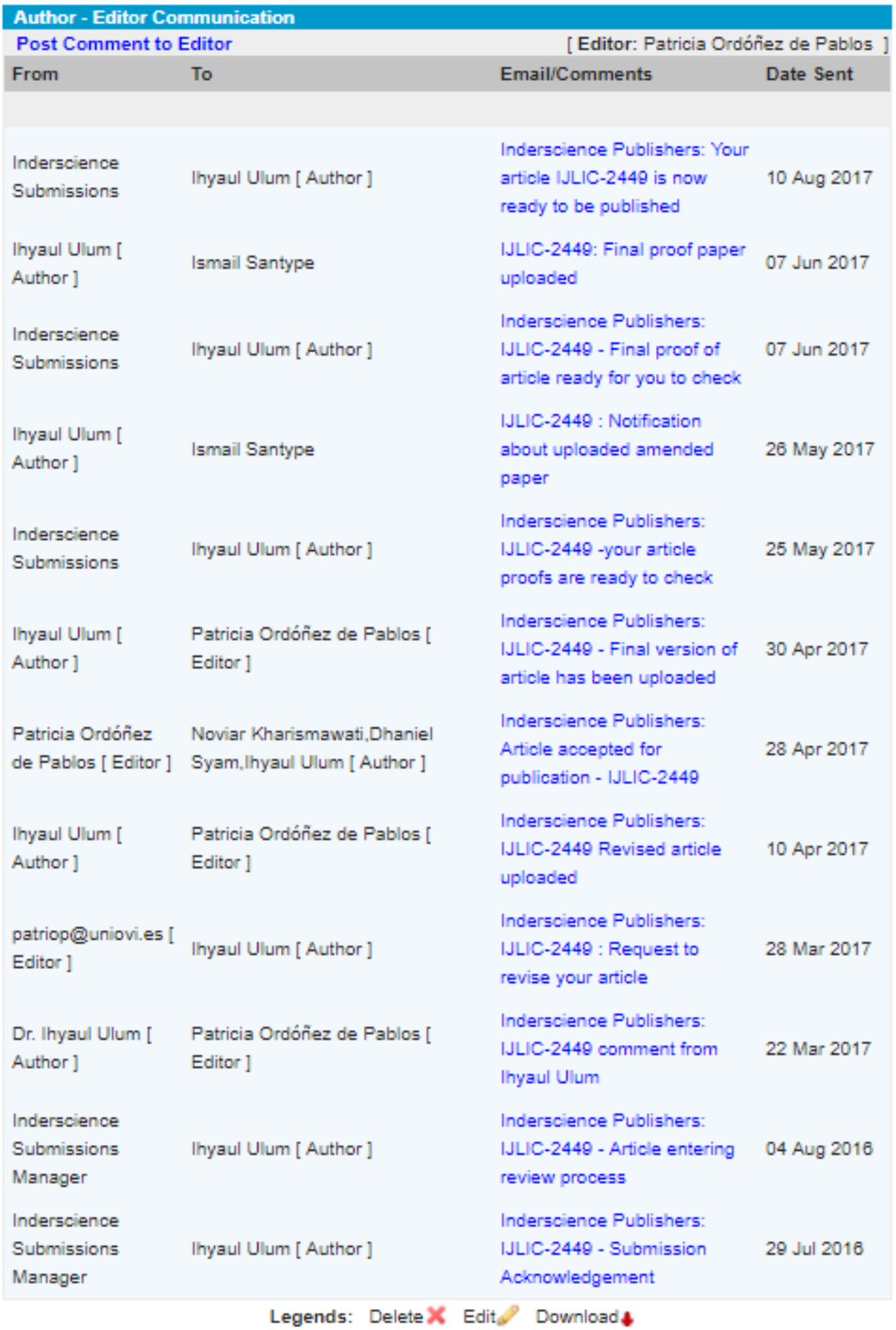




\section{Author details}

About Scopus Author Identifier

i The Scopus Author Identifier assigns a unique number to groups of documents written by the same author via an algorithm that matches authorship based on a certain criteria. If a document cannot be confidently matched with an author identifier, it is grouped separately. In this case, you may see more than one entry for the same author.

\section{Ulum, Ihyaul}

Universitas Muhammadiyah Malang, Malang,

Indonesia

Author ID: 57191663625

Other name formats:

Ulum, Ilhyaul

Subject area:

Social Sciences Business, Management and Accounting Engineering Energy
Economics, Econometrics and Finance Computer Science Mathematics Environmental Science

吕Print Email

Follow this Author

View potential author matches

Environmental Science
IU Ulum, Ihyaul

Universitas

Muhammadiyah Malang

Is this you?

$h$-index: (3)

1 
Document and

citation trends:

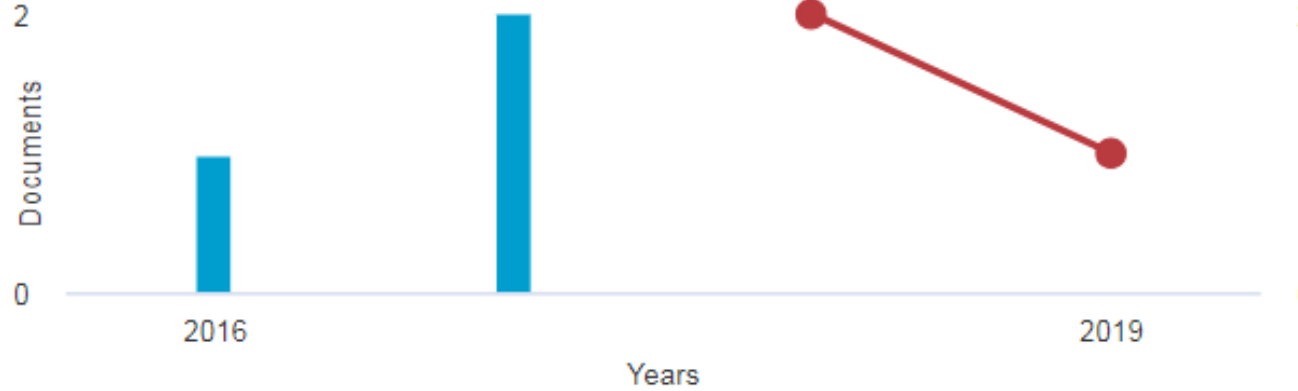

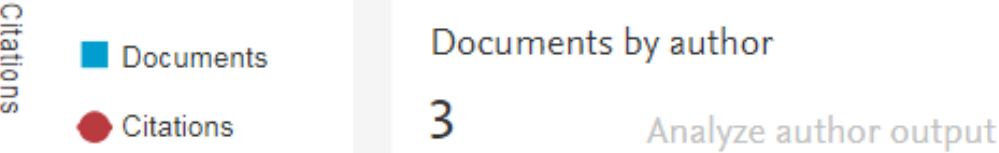

Years

Total citations

3 by 3 documents

\section{Documents Cited by 3 documents 8 co-authors Author history}




\section{Export all Add all to list Set document alert Set document feed}

\section{Document title}

Authors

Year Source

Cited by

Does intellectual capital disclosure enhance organization governance? Evidence from Indonesian biggest organizations

Mohamed, N., Abdullah, A.

View abstract $\vee$ Related documents

Modified value-added intellectual coefficient (MVAIC) and traditional financial performance of Indonesian biggest companies

View abstract $\vee$ Related documents
Ulum, I., Rizqiyah, Jati, A.W. non-financial industry of Indonesian biggest companies
Ulum, I., Kharismawati, N., Syam, D.

View abstract $\vee$ Related documents
2017 International Journal of Learning and Intellectual Capital 